\title{
ETIKA DALAM PANDANGAN AL-FARABI
}

\author{
Muhammad Syafi'i \\ Pascasarjana UIN Sunan Kalijaga
}

Diterima tanggal 14 November 2017 / Disetujui tanggal 29 Desember 2017

\begin{abstract}
Ethics is a philosophical part of axiology and becomes an important basis in the formation of morality. Today, ethics even becomes a serious individual matter that has an impact on human social life. There are many Islamic philosophers who highlight the theme of ethics within the philosophical framework, one of them is Abu Nasr Mubammad al-Farabi. His view of buman action and especially of happiness shows his different mind from the previous philosopher. His view of happiness reflects the orientation of human life in the present that overriden by the crisis of existence. In addition, some of his essays even focus exclusively on ethical discussions. Unfortunately, only a few scholars studied his ethical mind in a brief sub-section. Therefore, this paper will try to fill the void, as well as to contribute about the importance of ethics for the sustainability of individual morality and social morality.
\end{abstract}

Kata kunci: etika, kebaikan, kebahagiaan.

\section{Pendahuluan}

Diskusi tentang etika adalah salah satu pembicaraan paling tua sepanjang sejarah. Ini terutama diawali oleh para filsuf yang tertarik pada eksistensi manusia, yang di dalamnya disinggung persoalan tentang tingkah laku manusia. Diketahui bahwa etika mulai didiskusikan pertama kali oleh murid-murid Phytagoras (570-496 SM) yang mempersoalkan 
tentang metode penyucian diri sebagai norma etis dalam mengatur tingkah laku sehari-hari. ${ }^{1}$ Kemudian dilanjutkan oleh Demokritus (460-371 SM) dan kalangan kaum Sofis (abad ke-5 SM), serta dalam tulisan-tulisan serius yang dihasilkan oleh Plato (427-347 SM) dan Aristoteles (384-322 SM), adapun Sokrates yang menulis, "kita sedang membicarakan masalah yang tidak kecil, yakni mengenai bagaimana kita harus hidup". ${ }^{2}$

Jika kita melihat dalam Islam sendiri, etika sesungguhnya pembicaraan yang menjadi esensi dari ajaran agama. Bahkan sejak awal kehadiran Islam di dunia, ajaran yang sangat ditekankan dan menjadi fondasi bagi Islam itu sendiri adalah etika. Al-Qur'an menyebutkan dalam QS. al-Qalam: 4 yang artinya: dan sesunggubnya engkau benar-benar berbudi pekerti yang lubur, dan dalam hadits yang masyhur disebutkan sesunggubnya aku (Muhammad) diutus untuk menyempurnakan akblak. Dalam hal ini tampak, etika tidak hanya menjadi persoalan pokok dalam agama, tetapi juga kehidupan manusia secara universal. Etika mengharuskan manusia memilih jalan hidup dan caranya bertindak agar ia bisa mencapai kebahagiaan. Tentu, memilih jalan hidup dan mempertimbangkan cara bertindak yang baik dan benar adalah bagian dari moral. Konsep moral sendiri berlandaskan pada etika. ${ }^{3}$

Mengenai etika ini, sebagian kalangan pemikir barat menyangka bahwa landasan aturan-aturan etika tidak lain berasal dari perintah, larangan, kewajiban, dan ancaman. Dengan kata lain, hakikat aturan-aturan itu adalah anjuran. Karenanya pengetahuan etika dianggap tidak bernilai sebagai kebenaran. Maka mereka meyakini bahwa semua aturan itu tidak memiliki patokan kebenaran dan kesalahan. Bahkan, tidak mungkin ada tolak ukur untuk mengenali kebenaran atau kegalatan mereka. ${ }^{4}$

Sebagaimana diketahui, etika pertama kali dibicarakan oleh para filsuf Yunani. Pasca era Yunani, Islam bangkit sebagai sebuah agama sekaligus sebagai kekuatan baru dalam pencapaian pengetahuan. Karenanya kemudian, para pemikir Muslim banyak belajar pada filsuf Yunani, tidak hanya dalam etika tetapi juga berbagai kajian lainnya seperti ontologi.

Banyak pendapat yang menyatakan bahwa tradisi filsafat Islam bukanlah tradisi yang orisinil melainkan berasal dari pikiran-pikiran Yunani. Pernyataan ini tampak ada benarnya,

${ }^{1}$ K. Bertens, Sejarah Filsafat Yunani (Yogyakarta: Kanisius, 1975), 34-35.

${ }^{2}$ Muhammad Taufik, "Etika dalam Perspektif Filsafat Islam" dalam Zuhri, Etika: Teori dan Praktek, (Yogyakarta: FA Press, 2016), 36

${ }^{3}$ Zuhri, Etika: Teori dan Praktek (Yogyakarta: FA Press, 2016), 65.

${ }^{4}$ Muhammad Taqi' Mishbah Yazdi, Philisophical Instructions: An Introduction to Contemporary Islamic Philosophy, terj. Musa Kazhim dan Saleh Bagir (Bandung: Mizan, 2003), 154. 
karena faktanya memang beberapa buku-buku karya Aristoteles dan Plato diterjemahkan ke dalam bahasa Arab. ${ }^{5}$

Salah satu filsuf Islam yang menggali pemikiran filsuf Yunani dengan sangat serius adalah al-Farabi. Ia merupakan filsuf klasik awal yang berusaha menggaungkan filsafat di dunia Islam. Pikiran-pikirannya banyak terilhami dari para filsuf Yunani, terutama Aristoteles dan Plato. Berbagai tema-tema pokok mengenai filsafat hampir semua dibahas olehnya, salah satunya yang jarang menjadi fokus kajian serius saat ini adalah gagasan etika yang dikemukakannya. Karena itu, tulisan ini akan mencoba mengetengahkan bagaimana gagasan etika yang dibangun oleh al-Farabi, terutama prinsip-prinsipnya tentang kehidupan yang bahagia dan bagaimana cara mencapai kebahagiaan yang sesungguhnya. Melalui pemahaman al-Farabi tentang etika, pengamatan kita terhadap konsep etika yang dibangun sesudahnya sangat mungkin akan lebih mudah dipahami, karena al-Farabi termasuk tokoh filsuf Islam awal yang concern pada etika.

\section{Riwayat Hidup al-Farabi}

Nama lengkapnya adalah Abu Nasr Muhammad ibn Muhammad ibn Tarkhan ibn Uzlaq al-Farabi. Beliau lahir pada tahun $874 \mathrm{M} / 260 \mathrm{H}$ di Farab (Transoxia) yang terletak dalam wilayah Wasij di Turki. Ayahnya merupakan seorang anggota tentara yang miskin tetapi semua itu tidak menghalanginya mendapat pendidikan di Baghdad. ${ }^{6}$ Beliau mempelajari bahasa Arab di bawah pimpinan Ali Abu Bakr Muhammad ibn al-Sariy, juga pada seorang penterjemah Abu Bisr Matta ibn Yunus. Tidak berhenti di situ, ia melanjutkan perjalanannya menuntut ilmu ke Harran, pusat kebudayaan Yunani di Asia Kecil dan berguru kepada Yuhanna ibn Jailan, tetapi ia tidak lama berada di sini. Ia kembali ke Baghdad dan mengggunakan waktunya untuk berdiskusi, mengarang, dan mengulas bukubuku filsafat. ${ }^{8}$

Pada tahun $330 \mathrm{H} / 945 \mathrm{M}$, ia pindah ke Damaskus dan berkenalan dengan Saif alDaulah al-Hamdani, Sultan Dinasti Hamdan di Aleppo. Karena melihat kecerdasan alFarabi dalam ilmu agama sekaligus ilmu pengetahuan, maka Sultan memutuskan untuk

${ }^{5}$ Seyyed Hosein Nasr, Three Muslim Sages: Avicenna-Subrawardi-Ibn 'Arabi, terj. Ach. Maimun Syamsuddin (Yogyakarta: IRCiSoD, 2014), 14.

${ }^{6}$ Ayi Sofyan, Kapita Selekta Filsafat (Bandung: Pustaka Setia, 2010), 319.

${ }^{7}$ Mardzelah Makhsin. Sains Pemikiran dan Etika (Kuala Lumpur: PTS Professional Publishing Sdn, Bhd, 2006), 95.

${ }^{8}$ Sirajuddin Zar, Filsafat Islam: Filosof dan Filsafatnya (Jakarta: RajaGrafindo Persada, 2012), 66. 
mengajaknya ke Aleppo dan tinggal di Istana Saif al-Daulah. Di sinilah ia banyak bergelut dengan ilmu pengetahuan dan filsafat.'

Al-Farabi terdidik dengan sifat qana'ah sehingga menjadikannya sebagai orang yang sederhana, tidak gila harta dan terjebak pada keinginan duniawi. Ia lebih memfokuskan diri untuk mencurahkan perhatiannya pada pencarian ilmu ketimbang melibatkan diri untuk tujuan mencari kekayaan materi. Karena hal inilah, ia hidup dalam keadaan yang miskin sepanjang hidupnya dan meghembuskan nafas terakhirnya pada $950 \mathrm{M}(339 \mathrm{H})$ di usia 80 tahun. ${ }^{10}$ Tetapi perlu digaris bawahi bahwa sekalipun pribadinya sangat luhur, ia bukanlah ahli sufi. Ia justru dikenal sebagai ilmuan yang cukup terkenal pada zamannya, yang mampu menguasai berbagai bahasa. Ilmu-ilmu yang dikuasai al-Farabi antara lain bidang kedokteran, sains, matematika, sejarah, musik, logika, kimia, bahasa dan filsafat. Di antara kesekian ilmu itu, filsafatlah yang menjadi kegemarannya. Kehebatannya dalam bidang ini bahkan melampaui al-Kindi dan Ibnu Rusyd. ${ }^{11}$

Selama masa hidupnya, al-Farabi juga banyak mengkaji pemikiran-pemikiran Socrates, Plato, dan Aristoteles mulai dari persoalan wujud sampai kepada konsep kebahagiaan. Tidak heran kemudian jika ia dikenal sebagai orang yang paling memahami filsafat Aristoteles. ${ }^{12}$ Ini terbukti dengan lahirnya ilmu logika Yunani yang disusun secara teratur dalam bahasa Arab. Meskipun pemikirannya banyak dipengaruhi oleh Yunani, tetapi tidak semua dari Yunani diadopsi ke dalam pemikirannya, beberapa bahkan ditolak dan diluruskan, misalnya ia menentang pendapat Plato yang menganjurkan konsep pemisahan dalam kehidupan manusia. ${ }^{13}$

Pemikir Barat seperti Massignon, ahli ketimuran Perancis mengemukakan bahwa alFarabi adalah filsuf Muslim yang mamiliki kapasitas tangguh dalam menafsirkan pikiranpikiran Yunani, terutama Aristoteles. Meskipun kenyataannya al-Kindi yang membuka keran bagi tumbuhnya filsafat, tetapi pikiran al-Farabilah yang sangat fenomenal. ${ }^{14}$ Al-Farabi merupakan filsuf Islam yang dianggap paling menguasai pikiran-pikiran filsafat Aristoteles, terutama dalam bidang logika. Kehebatannya ini membuat orang-orang terkesan dan

${ }^{9}$ Maftukhin, Filsafat Islam (Yogyakarta: Teras, 2012), 97.

${ }^{10}$ Sirajuddin Zar, Filsafat Islam: Filosof dan Filsafatnya, 66.

${ }^{11}$ Mardzelah Makhsin, Sains Pemikiran dan Etika, 95.

${ }^{12}$ Yamani, FilsafatPolitik Islam: Antara al-Farabi dan Khomeini (Bandung: Mizan, 2002), 54-55.

${ }^{13}$ Mardzelah Makhsin, Sains Pemikiran dan Etika (Kuala Lumpur: PTS Professional Publishing Sdn, Bhd, 2006), 95.

${ }^{14}$ A. Hanafi, M.A. Pengantar Filsafat Islam (Jakarta: Bulan Bintang, 1969), 89. 
menjulukinya sebagai Mu'allim al-Tsani (Guru Kedua). ${ }^{15}$ Melihat kontribusinya yang sangat berharga bagi khazanah intelektual Islam pada masanya dan generasi setelahnya maka wajar jika predikat Guru Kedua itu disandangnya. Ia sangat konsen dengan dunianya dalam pergumulan intelektual. Dari pergumulannya itu pula, ia menjadi filosof yang produktif. ${ }^{16}$

Ada banyak karangan yang ditinggalkan oleh al-Farabi, namun karangankarangannya tidak banyak dikenal sebagaimana karangan-karangan Ibnu Sina. Alasan yang memungkinkan dikarenakan karyanya hanya berupa risalah-risalah pendek, sedikit yang berupa buku besar yang pembahasannya mendalam. Ada sekitar kurang lebih 30 buah karyanya yang ditulis dalam bahasa Arab. ${ }^{17}$

Beberapa di antara karyanya yaitu: Maqalat fi Agradl mâ Ba'da at-Thabî'at, al-Jam'u baina Ri'jâl al-Hakimain, Tabshîl as-Sa'âdah, 'Uyûn al-Masâil, Arâ-u Abl al-Madînah al-Fadhîlah, Ihsha' al-Ulùm, Fushûl al-Hukem, al-Siyâsah al-Madaniyyah, Risalât al-'Aql. ${ }^{18}$

\section{Etika dalam Tinjauan Filosofis: Dari Yunani Menuju Islam}

Sebagaimana kemunculannya di Yunani, etika asal katanya berasal dari negeri tersebut yaitu ethos, dengan bentuk jamak ta etha. Ethos memiliki makna yang plural yaitu, tempat tinggal yang biasa, padang rumput, kandang, kebiasaan, adat, akhlak, watak, perasaan, sikap, dan cara berfikir. Sementara kata ta etha berarti adat kebiasaan. Pengertian terakhir ini yang menjadi sumber bagi adanya kata etika dengan tokohnya yaitu Aristoteles yang menunjukkan pengertian mengenai filsafat moral. Maka dari itu, etika secara etimologi berarti ilmu tentang apa yang biasa dilakukan atau ilmu tentang adat kebiasaan. ${ }^{19}$

Etika dalam kajian filsafat adalah studi mengenai penyelidikan pada kewajibankewajiban manusia serta tingkah lakunya dilihat dari segi baik dan buruk. Etika juga memiliki sifat yang sangat mendasar berupa mempersoalkan tentang norma-norma yang berlaku dalam suatu masyarakat. Persoalan etika juga berhubungan dengan eksistensi manusia dalam segala aspeknya, baik individu maupun masyarakat, baik hubungannya dengan Tuhan maupun dengan sesama manusia dan dirinya. ${ }^{20}$

\footnotetext{
${ }^{15}$ Sirajuddin Zar, Filsafat Islam: Filosof dan Filsafatnya (Jakarta: RajaGrafindo Persada, 2012), 67.

${ }^{16}$ M. M. Syarif, Para Filosof Muslim (Bandung: Penerbit Al Mizan, 1985) 55-57.

${ }^{17}$ A. Hanafi, M.A. Pengantar Filsafat Islam, 89.

${ }^{18}$ Sirajuddin Zar, Filsafat Islam: Filosof dan Filsafatnya, 67-68.

${ }^{19}$ K. Bertens, Etika (Jakarta: Gramedia, 1993), 4.

${ }^{20}$ Musa Asy'arie, Filsafat Islam Sunah Nabi dalam Berfikir (Yogyakarta: LES-FI, 2001), 91.
} 
Sebagaimana telah disinggung di bagian awal bahwa etika muncul pertama kali di kalangan murid-murid Phytagoras (570-496 SM). Mereka merupakan kaum yang menganut ajaran reinkarnasi di samping mempercayai bahwa prinsip-prinsip matematika merupakan dasar segala realitas. Bagi mereka, badan adalah kuburan bagi jiwa. Jiwa dapat bebas dari badan atau bisa terbebas dari lingkaran perpindahan jiwa yang terus menerus bereinkarnasi, maka manusia perlu melakukan pensucian diri dengan cara bertapa, berfilsafat, dan memenuhi aturan-aturan tertentu. Berdasarkan hal inilah mereka melakukan tindakan dalam kehidupan sehari-hari dan ini menjadi norma etis yang mengatur pola kehidupan mereka. ${ }^{21}$

Pada tahap selanjutnya, etika mulai mengalami perkembangan dan diperbincangkan dalam ajaran Demokritus (460 - 371 SM). Etika di sini terutama berkaitan dengan pandangan hidup tertinggi manusia yang disebut sebagai euthymia, yaitu keadaan batin yang sempurna. Keadaan batin yang sempurna ini bisa ditempuh melalui penyeimbangan semua faktor yang ada dalam kehidupan. Adapun tolak ukurnya adalah kesenangan manusia. Ajaran ini mengutamakan agar manusia mengatur hidup dengan sebaik-baiknya dan sesempurnanya, sehingga pada akhirnya ia bisa mendapatkan kesenangan yang banyak dan kesusahan yang sedikit. ${ }^{22}$

Dari sudut pandangan yang berbeda, muncul ajaran etika yang digagas oleh kaum Sofis (abad ke-5 SM). Mereka mempertanyakan dalil-dalil moralitas tradisional sebelumnya. Mereka menegaskan bahwa baik dan buruk merupakan masalah keputusan masing-masing atau kesepakatan bersama dari suatu aturan abadi dan universal. Baik dan buruk sifatnya relatif dan tergantung manusia yang bersangkutan yang menilainya. Oleh karena itu, pandangan ini merupakan tonggak bagi berdirinya paham relativisme moral yang menyandarkan segala tindakan berpusat kepada manusia. ${ }^{23}$

Setelah ini barulah muncul Plato dan Aristoteles yang mencoba memberikan penjelasan rinci tentang etika. Namun disayangkan, Plato tidak meninggalkan satu karyapun tentang etika, meskipun demikian, pikirannya lebih banyak bisa dilihat dalam dialog-dialog yang bersifat etis. Beberapa kata kunci yang sering menjadi perbicangan Plato adalah Sang Baik dan Idea Tertinggi, Sang Baik merupakan Idea Tertinggi dalam gagasannya tentang ide. Baginya tujuan hidup manusia adalah mencapai Sang Baik lewat pengenalan akal budi, dan membebaskan diri dari kekuasaan irasional hawa nafsu dan emosi. ${ }^{24}$ Berbeda halnya dengan

${ }^{21}$ Franz Magniz-Suseno, 13 Tokoh Etika: Sejak Zaman Yunani Sampai Abad ke-19 (Yogyakarta: Kanisius, 1997), 12.

${ }^{22}$ K. Bertens, Sejarah Filsafat Yunani, 34-35.

${ }^{23}$ K. Bertens, Sejarah Filsafat Yunani, 70.

${ }^{24}$ Franz Magniz-Suseno, 13 Tokoh Etika: Sejak Zaman Yunani Sampai Abad ke-19, 16-23. 
Aristoteles, ia berhasil mengarang beberapa karya sistematis mengenai etika, yaitu Ethika Eudemia, Ethika Nikomacheia, dan Politike. ${ }^{25}$

Di antara tiga buku Aristoteles tersebut satu di antaranya berhasil diterjemakan ke dalam bahasa Arab oleh Hunayn bin Ishaq yang terkenal dengan kitab Niqumakhiyah. ${ }^{26}$ Dari sinilah kemudian teks-teks etika muncul dalam dunia filsafat Islam, terutama melalui pikiran filsuf awal seperti al-Kindi dan al-Farabi. Al-Farabi bahkan berhasil menjadi salah satu komentator bagi pikiran-pikiran etika Aristoteles tersebut.

\section{Konsep Etika al-Farabi}

Al-Farabi adalah penerus tradisi intelektual al-Kindi, tetapi kompetensi, kreativitas, kebebasan berfikir dan tingkat sofistikasinya lebih tinggi lagi. Jika al-Kindi dipandang sebagai seorang filsuf Muslim dalam arti kata yang sebenarnya, maka al-Farabi disepakati sebagai peletak sesunggunhya dasar piramida studi filsafat dalam Islam yang sejak itu terus dibangun dengan tekun. Ia termasyhur karena telah memperkenalkan doktrin "Harmonisasi pendapat Plato dan Aristoteles" lewat risalahnya al-Jam'u baina Ra'yay al-Hakimaini Aflathun wa Aristhu ini sangat dipengaruhi oleh pandangan Plato (Republic) dan Aristoteles (Nicomachean Ethics) tentang kebaikan manusia (buman good). Bahkan sejumlah kalangan menyebutnya sebagai the Second Master atau Maha Guru Kedua setelah Aristoteles. ${ }^{27}$

Dari perspektif para filsuf Muslim, etika dalam Islam (al-akblaq) disinggung dalam berbagai ruang dan perspektif. Al-Kindi misalnya, memperbincangkan etika Islam dalam konteks obsesi, dia ingin memformulasikan titik temu antara ide-ide filosofis di satu sisi dengan keyakinan-keyakinan dalam Islam baik dalam ranah metafisika, kosmologi, dan etika. Hal itu sebagaimana tercermin dalam mode of philosophic taubid di mana Allah diposisikan sebagai al-wâhid al-haqq al-awwal.

Sementara al-Farabi lebih jauh masuk dan fokus merincikan persoalan tersebut. AlFarabi menulis al-Madînah al-Fadbîlah dan Takhshîl al-Sa'âdah. Dengan dua karya tersebut, virtues (eudomonia) menjadi state of mind bagi umat manusia untuk melakukan tindakan kebaikan. Pada saat yang sama, usaha-usaha untuk membentuk jati diri individu dan masyarakat yang memiliki basis etika yang baik harus dijalankan oleh sistem sosial

\footnotetext{
${ }^{25}$ Franz Magniz-Suseno, 13 Tokoh Etika: Sejak Zaman Yunani Sampai Abad ke-19, 25.

${ }^{26}$ Ghulamriza A'wani, “Transfer of Ethical Texts to The Islamic World” dalam Behruz Rafiee, Ethics in Islam (Tehran: Alhoda, 2004) 26. I, Cet. I, 962.

${ }^{27}$ Seyyed Hossein Nasr \& Oliver Leaman, History of Islamic Philosophy (London: Routledge, 1996), Vol.
} 
(pemerintah) yang juga baik. Oleh karena itu, al-Farabi lebih memposisikan gagasan-gagasan etika dalam pemikirannya ke konsep besar politik di satu sisi dan konsep metafisika di sisi lain.

Dengan prinsip demikian, al-Farabi membagi keutamaan (yang harus dibangun dan disadari oleh setiap manusia ke dalam empat macam: keutamaan teoritis (al-fadhail alnazhraiyyah), keutamaan epistemik (al-fadhâil al-fikriyyah), keutamaan kosmis (al-fadhâil alkhalqiyyah) dan keutamaan praksis (al-fadhâil al-'amaliyyah). ${ }^{28}$

Sebagai seorang tokoh awal yang serius dalam bidang filsafat, konsep etika yang ditawarkan al-Farabi menjadi salah satu hal penting dalam karya-karyanya, yang berkaitan erat dengan pembicaraan tentang jiwa dan politik. Begitu juga erat kaitannya dengan persoalan etika ini adalah persoalan kebahagiaan. ${ }^{29}$ Bahkan, Al-Farabi tampaknya sangat perhatian terhadap persoalan kebahagiaan ini baik secara teoritis maupun praktis. Karenanya ia mengkhususkan dua dari sekian bukunya untuk membahas tentang kebahagiaan. Buku itu yaitu Tahshîl al-Sa'âdah (Meraih kebahagiaan) dan al-Tanbîh al Sa'âdah (Membangun Kebahagiaan), kedua buku ini sama-sama diterbitkan di Haidarabad pada tahun $1345 \mathrm{H}$, $1346 \mathrm{H}^{30}$

Secara umum, terdapat dua pandangan tentang kebahagiaan manusia yang terlihat berbeda, yaitu: Pertama, yang bersifat teoretis yang dipaparkan dalam karyanya al-Madinah alFadbilah (On the Perfect State) dan al-Siyasah al-Madaniyyah (The Political Regime). Kedua, yang mengadopsi bentuk pemikiran Plato dalam bidang filsafat dan politik yang termaktub dalam Tabshîl al-Sa'âdah (The Attainment of Happiness). Pandangan pertama menegaskan bahwa kebahagiaan manusia dapat diidentifikasi melalui aktifitas yang dilakukan oleh jiwa yang terpisah dari badan. ${ }^{31}$

Beberapa pokok pikiran al-Farabi mengenai etika terbagi ke dalam macam yaitu:

\section{Tindakan Manusia}

Al-Farabi dalam memahami tentang manusia berusaha berkonsentrasi untuk menjelaskan al'amal iradi (aksi vilisional). Dengan ini, ia membedakan irâdah dari ikhtiar, ia berpendapat bahwa irâdah (kehendak) dilahirkan oleh rasa rindu dan keinginan yang dibangkitkan oleh rasa dan imajinasi. Sementara ikhtiar semata-mata dilahirkan oleh

28Zuhri, Etika: Teori dan Praktek, 74-75.

${ }^{29}$ Seyyed Hossein Nasr \& Oliver Leaman, History of Islamic Philosophy, Vol. I, Cet. I, 962.

${ }^{30}$ Ibrahim Madkour, Filsafat Islam: Teori dan Penerapannya (Jakarta: RajaGrafindo Persada, 1996), 33.

${ }^{31}$ Seyyed Hossein Nasr \& Oliver Leaman, History of Islamic Philosophy, Vol. I, Cet. I, 963. 
pemikiran dan analisa. Seolah-olah ia menurunkan pengertian kehendak ke dalam standar kecenderungan, karenanya dimungkinkan jatuh ke alam hewani. Akan tetapi di tempat lain, Al-Farabi berusaha menganalisis tingkat-tingkat 'amal iradi, yang kemudian dihubungkan secara erat dengan niat dan qasd. Niat baginya sangat jelas mendahului dan tidak bersamaan dengan aksi dan disebut 'azam - yaitu persoalan yang disimpan oleh hati bahwa Anda akan melakukan hal itu. Sedangkan qasd (unsur kesengajaan) menurut alFarabi terjadi bersamaan dengan aksi. Baik niat, 'ąm, maupun qasd merupakan fenomena psikologis yang berlandaskan pada prinsip pikiran dan analisis.

Al-Farabi menjelaskan bahwa manusia bisa berbuat baik jika ia berkehendak, karena ia bebas untuk mewujudkan apa yang ia kehendaki dan perbuat. Akan tetapi, kebebasan ini tunduk kepada hukum-hukum alam, masing-masing diberi kemampuan sesuai dengan kejadiannya. Perhatian Allah mencakup segala hal dan berhubungan dengan setiap orang, dan setiap yang ada ini terjadi atas qadha dan qadar-Nya. Perhatian Tuhan adalah pengaturan kokoh dan universal yang tidak mengandung kontradiksi. Sebab, manusia memiliki bidang sedangkan alam memiliki sistem, di mana bidang manusia tidak akan terwujud kecuali jika memenuhi persyaratan kehendak. Hal ini mirip dengan teori harmonia pra estabilita yang dikemukakan oleh Leibniz sekitar tujuh abad setelah al-Farabi. ${ }^{32}$

Berdasarkan pandangannya tentang tindakan manusia, al-Farabi menyarankan agar manusia bertindak tidak berlebihan yang dapat merusak jiwa dan fisik, namun harus mengambil posisi tengah-tengah. Hal itu dapat ditentukan dengan memperhatikan zaman, tempat, dan orang yang melakukan hal tersebut, serta tujuan yang dicari, cara yang digunakan dan kerja yang memenuhi semua syarat tersebut. Berani, sebagai contoh, merupakan sifat terpuji yang terletak di antara dua sifat tercela, membabi buta (tahawwur) dan penakut $(j u b n)$. Kemurahan (al-karam) terletak antara dua sifat tercela, kikir dan boros (tabdzir). Memelihara kehormatan diri ('iffah) terletak antara dua sifat tercela, keberandalan (khala'ah) dan tidak ada rasa kenikmatan. ${ }^{33}$

\section{Kebahagiaan Sebagai Tujuan Akhir}

Sebagaimana disinggung sebelumnya bahwa kebahagiaan adalah pencapaian kesempurnaan sekaligus tujuan akhir manusia. Al-Farabi meyakini bahwa dengan

${ }^{32}$ Ibrahim Madkour, Aliran dan Teori Filsafat Islam, terj. Yudian Wahyudi Asmin (Jakarta: Bumi Aksara), 231-232.

${ }^{33}$ A. Hanafi, Pengantar Filsafat Islam, 110. 
menetapkan kebahagiaan sebagai tujuan akhir, manusia akan menjadi makhluk yang sesuai dengan kodratnya dan memiliki akhlak yang baik. Ini berarti bahwa setiap perbuatan manusia dilakukan untuk mencapai tujuan atau maksud tertentu, dan maksud tertinggi yang paling akhir adalah kebahagiaan. Ciri khas al-Farabi dalam pemikiran etikanya adalah apa yang ia katakan sebagai tindakan yang baik adalah yang berdasarkan atas pertimbangan pikiran (ratio), bukan berdasarkan pada kerohanian semata yang berpangkal pada pemberantasan kesenangan lahiriah untuk dapat membersihkan jiwa dan mencapai kesempurnaan dan kebahagiaan tertinggi, sebagaimana yang sering didengungkan oleh para sufi dalam usaha tasawufnya. Maka dari itu yang disebut dengan perilaku yang bermoral menurut al-Farabi adalah tindakan yang didasarkan pada pertimbangan akal dan rasio, karena akal kita sudah memiliki kemampuan untuk membedakan apa yang dikatakan baik dan apa yang dikatakan buruk. ${ }^{34}$

Dalam al-Madinah al-Fadhîlah, al-Farabi menjelaskan asal-usul konsep kebaikan dalam konstruksi rasionalitas manusia sebagai berikut: ${ }^{35}$

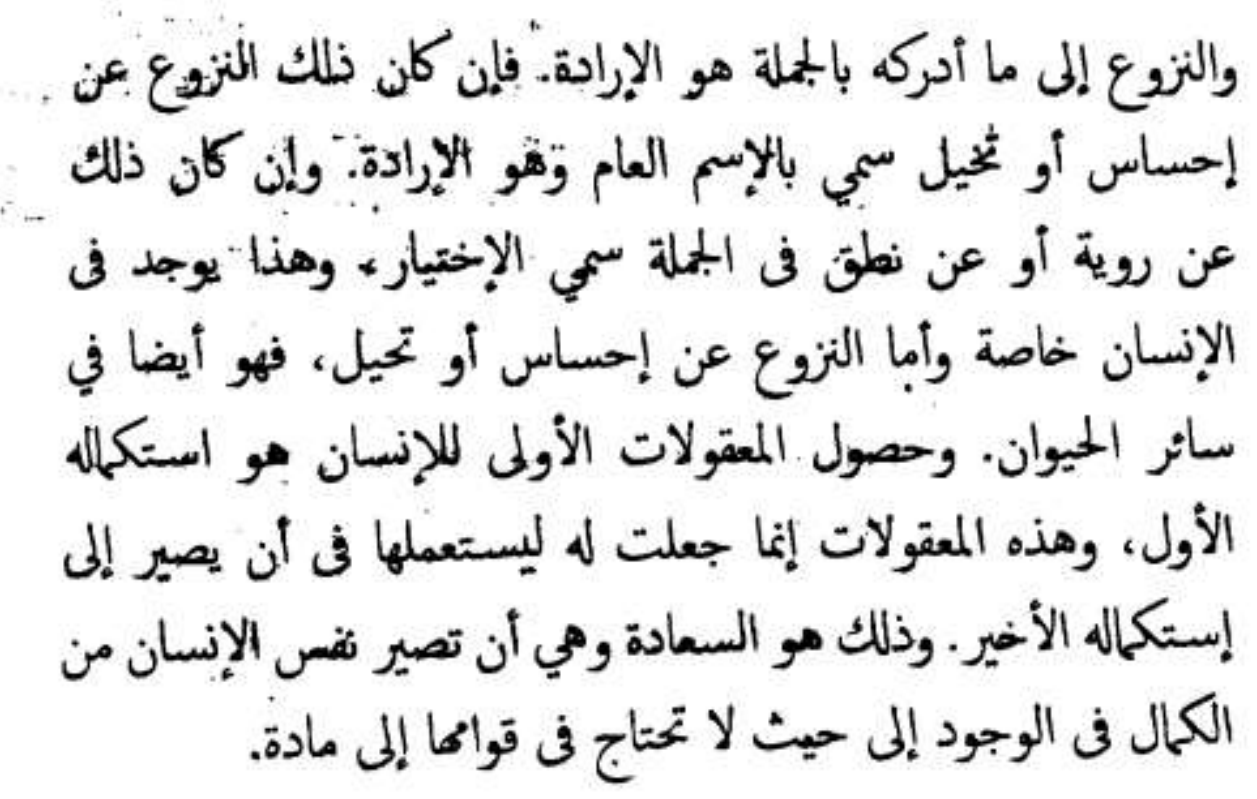

Etika yang menjadi gagasan al-Farabi ini mirip dengan apa yang menjadi etika menurut Aristoteles. Aristoteles juga meyakini hal yang sama, kebahagiaan sebagai

${ }^{34}$ A. Hanafi, Pengantar Filsafat Islam, 107.

${ }^{35} \mathrm{Abu}$ Nasr al-Farabi, Arâ' Ahl al-Madînah al-Fadhîlah (Cairo: Maktabah Azhariyyah), 182-183. 
tujuan akhir hidup manusia, dan untuk mencapai tujuan akhir itu diperlukan tindakan moral yang berdasarkan pada rasio. Misalnya, saya rajin belajar karena saya ingin mendapatkan pengetahuan, dengan pengetahuan yang banyak wawasan saya menjadi luas, dengan wawasan yang luas saya bisa memahami apa yang terjadi pada dunia dan manusia, dengan memahami hal tersebut akan membantu saya untuk melihat tandatanda ketuhanan, dan seterusnya. Berdasarkan hal ini, maka memang tidak bisa dibantah, bahwa pikiran al-Farabi tentang etika juga dipengaruhi oleh pandangan Aristoteles. ${ }^{36}$

Pikiran Aristoteles yang tak terbantahkan diadopsi oleh al-Farabi adalah dalam penjelasannya mengenai kebaikan tertinggi (Summum Bonum). Aristoteles di buku kesepuluh dari Ethique menjelaskan bahwa kebaikan tertinggi itu adalah suatu keutamaan yang tersusun di dalam kesatuan dengan analisa akal, dan berbeda dengan keutamaankeutamaan manusiawi lainnya yang berkaitan dengan tubuh. Yaitu potensi analisa yang dilakukannya sendiri serta mempersepsikan kebenaran mutlak dan keutamaan yang tertinggi karena ia berhubungan dengan sesuatu yang paling tinggi di dalam diri manusia yaitu akal. ${ }^{37}$

Namun, orisinalitas pikiran Al-Farabi sebagai seorang pemikir yang tidak sekadar melakukan plagiasi terhadap Aristoteles adalah pemikirannya tentang akal dan jiwa yang diaplikasikan ke dalam objek etika dalam upaya pencapaian kebahagiaan. Bagi al-Farabi, kebahagiaan jiwa tidak hanya diperoleh melalui badan dan perbuatan-perbuatan sematamata, namun yang pertama adalah melalui pikiran dan pemikiran. Memang ada beberapa keutamaan yang bersifat perbuatan badan, tetapi bila dibandingkan dengan keutamaankeutamaan pikiran dan bersifat teori maka tidak arti ada apa-apa, dan kalau keutamaan jenis yang pertama itu merupakan kebaikan, maka keutamaan jenis kedua merupakan raja kebaikan. ${ }^{38}$

Tempat bagi kebahagiaan sejati manusia berada pada tingkat akal mustafad, yang siap menerima emanasi seluruh objek rasional dari akal aktif. Dengan demikian, perilaku berfikir adalah perilaku yang dapat mewujudkan kebahagiaan manusia. ${ }^{39}$

Dalam menempuh jalan pertumbuhannya, akal manusia berjalan melalui beberapa fase yang bertingkat-tingkat. Awalnya akal tersebut adalah akal potensi ('aql bi al-quwwah), dan apabila ia telah banyak memperoleh objek-objek ilmunya dan kebenaran-

${ }^{36}$ Zuhri, Etika: Teori dan Praktek, 21-22.

${ }^{37}$ Ibrahim Madkour, Filsafat Islam: Teori dan Penerapannya, 41.

${ }^{38}$ A. Hanafi, Pengantar Filsafat Islam, 108.

${ }^{39}$ Muhammad Ustman Najati. Jiwa dalam Pandangan Paraf Filosof Muslim (Bandung: Pustaka Hidayah, 1993), 76. 
kebenaran umum (absolut), maka ia menjadi akal nyata (al-'aql bi al-fi' il). Kadang-kadang, akal bisa meluas daerah cakupannya, sehingga dapat mengetahui kebanyakan hal-hal yang universal, dan di sini ia mencapai tingkat tertinggi bagi manusia, yaitu tingkat akal mustafad atau yang disebut dengan tingkat pelimpahan dan turunnya ilham. ${ }^{40}$

Semakin banyak objek pengetahuan seseorang, maka ia semakin dekat menuju tingkatan alam yang lebih tinggi dan mendekati akal yang tidak ada pada benda. Kalau ia sudah mencapai tingkat akal mustafad, maka ia dapat menerima cahaya-cahaya ketuhanan dan dapat berhubungan langsung dengan akal kesepuluh. Jadi dengan ilmu dan ilmu itu semata-mata, kita dapat menghubungkan langit dengan bumi, antara alam ketuhanan dengan alam kemanusiaan, atau antara malaikat dengan manusia. Dengan ini kita bisa mencapai kebahagiaan yang sesungguhnya, karena kita telah melewati berbagai proses sehingga mampu melihat realitas yang sesungguhnya di balik realitas yang ada. ${ }^{41}$. Kebahagiaan yang bersifat teori dan metafisik merupakan tujuan termulia yang dicari oleh akal manusia. Jika tingakatan ini diperoleh, maka jiwa dapat terbebas dan mampu keluar dari semua perkara yang bersifat kebendaan, dan dapat berhubungan dengan alam pikiran yang di dalamnya terdapat kebahagiaan sejati atau kebahagiaan ideal yang sesuai dengan keinginan fitrah manusia, bukan keinginan hawa nafsunya. ${ }^{42}$ Berdasarkan pernyataan ini tampak bahwa al-Farabi juga mengambil upaya yang dilakukan oleh Plato, yaitu tentang dunia ide, dimana dunia ini adalah tempat hakikat realitas, wadah sesungguhnya bagi bertumpunya kebahagiaan yang nyata.

Kebahagiaan yang dituju oleh filsafat dan moral, diverifikasikan oleh teori dan praktik serta diusahakan oleh manusia melalui studi dan tingkah lakunya, adalah kebaikan mutlak dan puncak segala puncak, batas akhir ketinggian manusia dan surga bagi orang-orang yang mencapainya. Al-Farabi mengatakan:

"Kebahagiaan ialah jika jiwa manusia menjadi sempurna di dalam wujud di mana ia tidak membutuhkan, dalam eksistensinya kepada suatu materi. Hal itu dengan cara ia harus di dalam globalitas esensi yang terpisah dengan materi, ia harus abadi dalam kondisi itu, hanya saja tingkatannya berada di bawah 'aql fa' al. Tetapi ia bisa mencapai hal itu melalui tindakan-tindakan kehendak yang terdiri dari tindakan fikir dan tindakan fisik. Ia tidak cocok dengan tindakan apapun, tetapi dengan tindakan-tindakan terbatas dan tertentu yang bisa didapat melalui keadaan-keadaan tertentu yang benar-benar terbatas; hal itu dikarenakan di

\footnotetext{
${ }^{40}$ A. Hanafi, Pengantar Filsafat Islam, 108.

${ }^{41}$ Sudarsono, Filsafat Islam (Jakarta: Rineka Cipta, 2010), 75-76.

${ }^{42}$ A. Hanafi, Pengantar Filsafat Islam, 108.
} 
antara tindakan tindakan kehendak itu, ada tindakan yang bisa menghambat kebahagiaan. Kebahagiaan adalah kebahagiaan yang dicari karena dirinya sendiri - sama sekali ia tidak dicari kapanpun juga untuk dipergunakan meraih sesuatu yang lain dan di belakangnya tidak ada sesuatu yang lebih besar daripadanya yang mungkin diraih oleh manusia. Tindakan-tindakan yang berguna di dalam mencapai kebahagiaan adalah berbagai tindakan baik, keadaan dan bakat yang menimbulkan tindakan-tindakan ini, yaitu keutamaan-keutamaan. Keutamaankeutamaan ini bukan kebaikan karena dirinya sendiri, tetapi karena hal-hal yang ditarik dari suatu kebahagiaan. Perbuatan yang menghalangi kebahagiaan ini adalah kejelekan dan perbuatan-perbuatan jelek, sementara kondisi dan bakat yang menimbulkan perbuatan-perbuatan ini adalah segala kekurangan, kerendahan, dan kehinaan. ${ }^{43}$

Bagi al-Farabi, memang tidak semua orang mampu mencapai tingkat kebahagiaan ini, ia hanya hadir pada orang-orang yang memiliki jiwa yang suci yang dapat menembus dinding-dinding alam ghaib dan menaik ke alam cahaya dan kebahagiaan. Al-Farabi sendiri sudah membuktikan hal ini, dalam dirinya sudah tercermin perilaku dan pikiran-pikiran yang suci sehingga jiwanya pun mencapai kebahagiaan yang sejati. Dapat dibaca tentang kehidupan lahiriah al-Farabi, ia juga tidak terlena oleh materi dan keduniaan, ia bahkan hidup dengan sederhana dan bersikap zuhud, lebih suka menyendiri dan menjauh dari keramaian, seperti yang banyak disebutkan oleh penulis-penulis biografinya.

Pada akhirnya, dapat disimpulkan satu formula baru etika al-Farabi yang tidak ditemukan pada Aristoteles dan Plato. Al-Farabi berusaha menggabungkan keduanya dalam usaha pencapaian kebahagiaan sebagai tujuan akhir. Al-Farabi telah berpijak pada pengetahuan ilmiah dan rasional Aristoteles dalam berperilaku dan bertindak sehingga seseorang tidak keluar dari tindakan moral, lalu tujuan akhir kebahagiaannya didapatkan dari pikiran Plato, sehingga dia meyakini bahwa pencapaian akhir berdasarkan perilaku yang sesuai dengan moralitas tersebut akan membawa cita-cita akhlak yang sesungguhnya yang sesuai dengan apa yang ada di dunia ide.

${ }^{43}$ Ibrahim Madkour, Filsafat Islam: Teori dan Penerapannya, 32-33. 


\section{Kebahagiaan Sosial}

Al-Farabi adalah seorang filsuf Islam yang paling banyak membicarakan persoalan kemanusiaan, walaupun sebenarnya ia bukan orang yang berkecimpung dalam dunia kemasyarakatan. ${ }^{44}$ Ia banyak menggeluti dunia moral, politik, dan psikologi. Sekaligus juga dengan serius menggeluti tentang perilaku individu di samping juga membahas masalah kemasyarakatan. Tampaknya, ia merupakan salah satu kaum Peripatetik Arab yang paling serius mendalam sosiologi. ${ }^{45}$ Persoalan kemasyarakatan ini banyak dibicarakan dalam karya-karyanya terutama dalam al-Siyâsah al-Madaniyyah (Politik Kenegaraan) dan Arâ-u Abl al-Madînah al-Fadbîlah (Pikiran-Pikiran Penduduk Kota Utama). ${ }^{46}$

Secara umum tampak memang kedua kitab ini terlihat mengarah kepada pembahasan tentang politik, tetapi esensi dari keduanya sesungguhnya adalah berbicara tentang etika, yaitu etika bernegara sehingga sebuah bangsa bisa menjadi bangsa yang ideal dan sesuai dengan visi Islam. Tujuan akhimya yaitu kebahagiaan masyarakat atau kebahagiaan sosial akan terwujud.

Manusia menurut al-Farabi, bersifat sosial dan tidak mungkin hidup sendirisendiri. Manusia hidup bermasyarakat dan bantu membantu untuk kepentingan bersama dalam mencapai tujuan hidup yaitu kebahagiaan. ${ }^{47}$ Sebagaimana Plato, al-Farabi menekankan bahwa bagian-bagian sesuatu negeri sangat erat hubungannya satu sama lain dan saling bekerja sama sebagaimana satu anggota badan dengan anggota badan lainnya saling gotong-royong dan berelasi. Jika salah satu anggota badan ada yang tidak beres, tidak berfungsi atau mengalami kerusakan, maka akan terjadi ketidakseimbangan, dan anggota badan yang lain juga akan terkena dampaknya. Contoh sederhana semisal jantung jika tidak bekerja, maka semua anggota badan tidak akan berfungsi normal sebagaiman mestinya. Maka dalam sebuah negara, segala kepentingan pribadi dan egoisme yang ada pada individu harus dikesampingkan, dan didahulukan kepentingan umum, jika tidak maka akan terjadi ketimpangan, dan masyarakat yang baik menurut alFarabi tidak akan terwujud. ${ }^{48}$

\footnotetext{
${ }^{44}$ A. Hanafi, Pengantar Filsafat Islam, 104.

${ }^{45}$ Ibrahim Madkour, Aliran dan Teori Filsafat Islam, 231.

${ }^{46}$ A. Hanafi, Pengantar Filsafat Islam, 104.

${ }^{47}$ Sirajuddin Zar, Filsafat Islam: Filosof dan Filsafatnya, 82.

${ }^{48}$ A. Hanafi, Pengantar Filsafat Islam (Jakarta: Bulan Bintang, 1969), 104.
} 
Tiap-tiap anggota badan memiliki fungsi yang berbeda-beda sesuai dengan tugasnya, maka begitu juga dengan masyarakat dalam sebuah bangsa, masing-masing harus memiliki tugas tertentu. Kebahagiaan masyarakat akan terwujud dengan sempurna apabila ada pembagian kerja yang sesuai dengan keterampilan dan kemampuan individu masing-masing dengan berlandaskan rasa kesetiakawanan dan kerja sama. ${ }^{49}$

Dalam hal ini, masing-masing individu memiliki pekerjaan yang berbeda-beda sesuai dengan tujuan yang hendak dicapainya. Pekerjaan yang paling mulia adalah adalah yang berhubungan dengan tugas-tugas kepala masyarakat, karena kedudukan kepala negara dalam sebuah pemerintahan yang berkuasa sama dengan kedudukan jantung pada anggota badan. Jantung adalah sumber kehidupan, pusat koordinasi sekaligus keserasian. Karenanya menjadi kepala negara merupakan tugas terberat sekaligus yang paling mulia. Kepala negara tidak hanya semata-mata mengurusi urusan yang sifatnya politis saja, tetapi juga yang paling utama adalah akhlak, karena ia adalah panutan, pusat cerminan masyarakat. Maka dari itu, seorang pemimpin yang mampu memiliki sifat ini patut ditiru dan dijadikan contoh bagi masyarakatnya, sehingga sebuah masyarakat bisa dikatakan sebagai masyarakat yang bahagia. ${ }^{50}$

Al-Farabi juga menekankan empat jenis sifat utama yang harus menjadi perhatian untuk mencapai kebahagiaan di dunia dan di akhirat bagi bangsa-bangsa dan setiap warga negara, yaitu:

a. Keutamaan teoritis, yaitu prinsip-prinsip pengetahuan yang diperoleh sejak awal tanpa diketahui cara dan asalnya, juga yang diperoleh dengan kontemplasi, penelitian dan belajar.

b. Keutamaan pemikiran, adalah yang memungkinkan orang mengetahui hal yang bermanafaat dalam tujuan. Termasuk dalam hal ini, kemampuan membuat aturanaturan, karena itu disebut keutamaan pemikiran budaya (fadhâil fikriyah madaniyyah).

c. Keutamaan akhlak, bertujuan mencari kebaikan. Jenis keutamaan ini berada di bawah dan menjadi syarat keutamaan pemikiran. Sedangkan kedua jenis keutamaan tersebut terjadi dengan tabiatnya, dan bisa juga terjadi dengan kehendak sebagai penyempurna tabiat atau watak manusia.

d. Keutamaan amaliah, diperoleh dengan dua cara yaitu pernyataan-pernyataan yang memuaskan dan merangsang. ${ }^{.1}$

\footnotetext{
${ }^{49}$ Majid Fakhry, Etika dalam Islam,terj. Zakiyuddin Baidhawy, (Yogyakarta: Pustaka Pelajar, 1996), 65.

${ }^{50}$ Majid Fakhry, Etika dalam Islam,terj. Zakiyuddin Baidhawy, (Yogyakarta: Pustaka Pelajar, 1996), 66.

${ }^{51}$ Hasyimsyah Nasution, Filsafat Islam (Jakarta: Gaya Media Pratama, 2001), Cet. II, 43.
} 
Al-Farabi membagi masyarakat menjadi dua macam, yakni Masyarakat sempurna (al-kamilah) dan Masyarakat tidak sempurna (al-ghairu al-kamilah). ${ }^{52}$

a. Masyarakat sempurna (al-kamilah)

Bisa berbentuk masyarakat kota, bisa pula masyarakat yang terdiri dari beberapa bangsa yang bersatu dan bekerjasama secara internasional. Masyarakat sempurna sendiri diklasifikasikan menjadi tiga:

1) Masyarakat sempurna besar ('udhma) adalah gabungan banyak bangsa yang sepakat untuk bergabung dan saling membantu serta kerja sama (perserikatan bangsa-bangsa). Bisa berbentuk masyarakat kota, bisa pula masyarakat yang terdiri dari beberapa bangsa yang bersatu dan bekerjasama secara internasional.

2) Masyarakat sempurna sedang (wustha) adalah masyarakat yang terdiri atas satu bangsa yang menghuni disatu wilayah dari bumi ini (negara nasional).

3) Masyarakat sempurna kecil (sughra), adalah masyarakat yang terdiri atas para penghuni satu kota (negara kota). ${ }^{53}$

b. Masyarakat tidak sempurna (al-ghairu al-kamilah)

Masyarakat tidak sempurna atau belum sempurna disini adalah seperti masyarakat dalam satu keluarga atau masyarakat satu desa. Penghidupan sosial di tingkat desa, kampung, lorong dan keluarga. Perkembangan dari tidak/kurang sempurna menjadi sempurna menurut Al-Farabi bertingkat-tingkat. Mula-mula, masyarakat manusia berupa masyarakat yang terbesar, lalu menjadi masyarakat desa dan kampung, kemudian menuju ke masyarakat kota yang sempurna dan berpemerintahan. Al-Farabi berpandangan bahwa masyarakat sempuna ialah masyarakat yang mengandung keseimbangan diantara unsur-unsurnya. Perbedaannya hanyalah kalau unsur-unsur masyarakat itu mempunyai kebebasan individual yang lebih besar maka dalam diri manusia unsur-unsur itu lebih dikuasai dan diperintah oleh pusatnya. ${ }^{54}$

Pandangan ini didasari oleh pemikiran filsafatnya bahwa manusia tidak sama satu sama lainnnya, disebabkan banyak faktor, antara lain: faktor iklim dan lingkungan tempat mereka hidup dan faktor makanan. Faktor-faktor tersebut

\footnotetext{
52A'li Abdul Wahid Wafi, Al-Madinah Al-Fadhîlah Lil Farabi, (Mesir: Nahdhah, ttt), 38.

${ }^{53}$ A'li Abdul Wahid Wafi, Al-Madînah Al-Fadhîlah Lil Farabi, 38.

${ }^{54}$ A’li Abdul Wahid Wafi, Al-Madînah Al-Fadbîlah Lil Farabi, 39.
} 
banyak berpengaruh dalam pembentukan watak, pola pikir dan perilaku, orientasi atau kecendurangan serta adat kebiasaan. ${ }^{55}$

Negara utama (al-Madinah al-Fadhîllah) sebagai satu masyarakat yang sempurna (al-Mujtami' al-Kamilah) yang digambarkan Al-Farabi adalah suatu masyarakat yang lengkap bagian-bagiannya, diibaratkan sebagai suatu organ tubuh manusia dengan anggota yang lengkap. Masing-masing organ tubuh harus bekerja sesuai fungsinya. Apabila satu organ tubuh sakit, organ tubuh yang lain akan ikut merasakan. ${ }^{56}$

Untuk mewujudkan negara utama, ada beberapa kriteria yang ditetapkan oleh al-Farabi bagi seseorang untuk bisa menjadi kepala negara yang baik dan pantas menjadi pemimpin sebuah negara. Kriteria itu berupa sehat badan, anggota-anggota badan semuanya lengkap (tidak cacat), ingatan yang kuat, kecerdasan yang tinggi, tanggapan yang tepat, tutur kata yang baik, cinta kepada ilmu pengetahuan dan selalu menambah ilmu pengetahuan ke dalam diri, menghiasi diri dengan kejujuran sehingga bisa dipercaya, tidak rakus, dan menjauhkan diri dari kenikmatan materi dan duniawi. ${ }^{57}$

Kriteria ini sesungguhnya merupakan moralitas yang susah terwujud bersamaan pada diri seseorang, bahkan al-Farabi sendiri mengakuinya. Meskipun begitu, ia justru menambah lagi syarat tersebut, dan ini tampaknya yang membedakannya dengan pikiran Plato dan lebih dekat kepada Islam, yaitu bahwa kepala negara harus bisa mencapai ketinggian untuk mencapai akal fa'al yang menjadi sumber wahyu dan ilham baginya. Akal fa'al ini merupakan salah satu akal yang sepuluh akal disebutkan oleh al-Farabi dan akal ini yang memiliki pengaruh bagi alam semesta dan berbagai peristiwa yang terjadi di dalamnya. ${ }^{58}$

Dalam persoalan pencapaian menuju akal fa'al ini tampak bahwa idealisme al-Farabi lebih eksploratif ketimbang Plato. Jika Plato menghendaki agar para filsuf yang menjadi kepala negara sekaligus mengurusi berbagai urusan kemasyarakatan dan politik, maka al-Farabi berdasarkan pikirannya menyatakan bahwa kepala negara harus masuk ke dalam alam rohani dan ia harus lebih banyak mengabdi kepada kehidupan rohaninya ketimbang kehidupan jasmaninya, di samping ia juga harus

${ }^{55}$ A'li Abdul Wahid Wafi, Al-Madînah Al-Fadhîlah Lil Farabi, 39.

${ }^{56}$ A'li Abdul Wahid Wafi, Al-Madînah Al-Fadhîlah Lil Farabi, 41.

${ }^{57}$ A. Hanafi, Pengantar Filsafat Islam, 109.

${ }^{58}$ A. Hanafi, Pengantar Filsafat Islam, 109. 
terus aktif berhubungan dengan akal fa'al. Dengan kata lain, apa yang dikatakan Plato bahwa filsuf sekaligus penguasa negara setelah dikonsepsikan oleh al-Farabi berubah menjadi seorang hakim yang bijaksana dan memiliki ruh keislaman dalam dirinya. ${ }^{59}$

Dengan demikian, bagi al-Farabi seorang kepala negara yang telah memperoleh kebahagiaan hakiki dari kehidupan rohaninya tentu dapat menarik rakyatnya kepada dirinya dan mendidik jiwa mereka, serta membawanya naik kepada alam cahaya yang cemerlang. Tentu saja konsepsi negara utama semacam ini sangat susah untuk direalisasikan dan ini hanya berada dalam dunia ide al-Farabi. Dari sini tampak bahwa pikiran-pikiran al-Farabi tentang pencapaian kebahagiaan masyarakat adalah berupa ilmu yang lebih bersifat teori, dan bukan sesuatu yang bersifat realistis-pragmatis. Hal ini bisa dimaklumi karena ia memang hanya seorang pemikir dengan penjelahan pikirannya yang sangat luas.

\section{Penutup}

Al-Farabi merupakan filsuf Muslim yang sejak awal kemunculannya sebagai pemikir sangat besar perhatiannya terhadap berbagai persoalan kemanusiaan yang ada pada waktu itu. Perhatian ini ditunjukkan bahkan pada aspek individu dan sosial. Terilhami dari kebijaksanaan pikiran para filsuf Yunani, al-Farabi mencoba menemukan corak pemikiran versinya sendiri yang bersandar pada ajaran-ajaran Islam.

Pemikirannya dalam bidang kemanusiaan ini terutama tertuang dalam karyakaryanya yang berisi tentang etika. Pandangan al-Farabi mengenai etika terutama berkisar pada persoalan tindakan manusia dan cara manusia mencapai kebahagiaan. Mengenai tindakan manusia terlihat ada kecendrungan bahwa logika yang ia gunakan melalui terminologi kehendak Tuhan memberikan kebebasan yang terbatas pada manusia. Dalam arti bahwa tindakan manusia adalah apa yang sudah dikehendaki Tuhan. Ini mirip dengan terminologi yang digaungkan paham Jabariyah, namun dalam hal ini persoalan ini tidak terlalu jauh dibahas dan menjadi masalah masa itu.

Mengenai kebahagiaan, setidaknya Al-Farabi memberikan jalan pencapaian kebahagiaan yang sempurna melalui adanya istilah akal yang ia gunakan dalam epsitemologinya dalam jalan mencari pengetahuan sejati. Pencapaian tertinggi dan puncak manusia bisa merasakan kebahagiaan adalah ketika ia berhasil mencapai akal aktif, di mana melalui akal ini manusia mampu berhubungan melalui batinnya dengan alam semesta. Sementara untuk mencapai kebahagiaan sosial, al-Farabi membuat analogi sebuah

${ }^{59}$ A. Hanafi, Pengantar Filsafat Islam, 109. 
masyarakat seperti anggota tubuh, di mana untuk mencapai kebahagiaan, harus ada seperangkat tata aturan yang menjadi pedoman bagi masing-masing individu dalam melaksanakan fungsi sosialnya. Mengenai kebahagiaan sosial ini, al-Farabi sangat fokus pada fungsi sosial kepala negara dalam suatu masayarakat, bahkan al-Farabi merumuskan dengan sangat ketat mengenai atribut-atribut kedirian yang harus ada pada seorang kepala negara. Dalam hal ini tampaknya, rumusan etika al-Farabi memiliki kesinambungan dan pengaruh satu sama lain. Dengan kata lain, untuk mencapai kebahagiaan, diri individulah yang terlebih dahulu harus dibersihkan dan diperbaiki, setelahnya barulah manusia bisa mewujudkan tatanan sosial yang sesuai dengan tuntunan agama.

\section{DAFTAR PUSTAKA}

Asy'arie, Musa. Filsafat Islam Sunah Nabi dalam Berfikir, Yogyakarta: LES-FI, 2001.

A'wani, Ghulamriza "Transfer of Ethical Texts to The Islamic World" dalam Behruz Rafiee, Ethics in Islam. Tehran: Alhoda, 2004.

Bertens, K. Sejarah Filsafat Yunani. Yogyakarta: Kanisius, 1975.

Etika. Jakarta: Gramedia, 1993.

Fakhry, Majid. Etika dalam Islam, terj. Zakiyuddin Baidhawy. Yogyakarta: Pustaka Pelajar, 1996.

al-Farabi, Abu Nasr. Arẩu Abl al-Madînah al-Fadhîlah. Cairo: Maktabah Azhariyyah, tt.

Hanafi, A. Pengantar Filsafat Islam. Jakarta: Bulan Bintang, 1969. 
Madkour, Ibrahim. Aliran dan Teori Filsafat Islam, terj. Yudian Wahyudi Asmin. Jakarta: Bumi Aksara, tt.

. Filsafat Islam: Teori dan Penerapannya. Jakarta: RajaGrafindo Persada, 1996.

Maftukhin. Filsafat Islam. Yogyakarta: Teras, 2012.

Magniz-Suseno, Franz. 13 Tokoh Etika: Sejak Zaman Yunani Sampai Abad ke-19. Yogyakarta: Kanisius, 1997.

Makhsin, Mardzelah. Sains Pemikiran dan Etika. Kuala Lumpur: PTS Professional Publishing Sdn, Bhd, 2006.

Najati, Muhammad Ustman. Jiwa dalam Pandangan Para Filosof Muslim, Bandung: Pustaka Hidayah, 1993.

Nasr, Seyyed Hossein \& Oliver Leaman. History of Islamic Philosophy, Vol. I, Cet. I. London: Routledge, 1996.

Nasr, Seyyed Hosein. Three Muslim Sages: Avicenna-Subrawardi-Ibn 'Arabi, terj. Ach. Maimun Syamsuddin. Yogyakarta: IRCiSoD, 2014.

Nasution, Hasyimsyah. Filsafat Islam. Cet. II. Jakarta: Gaya Media Pratama, 2001.

Sofyan, Ayi. Kapita Selekta Filsafat. Bandung: Pustaka Setia, 2010.

Sudarsono. Filsafat Islam. Jakarta: Rineka Cipta, 2010.

Syarif, M. M. Para Filosof Muslim. Bandung: Penerbit Al Mizan, 1985. 
Wafi, A'li Abdul Wahid. Al-Madinah Al-Fadhîlah Lil Farabi. Mesir: Nahdhah, tt.

Yamani. FilsafatPolitik Islam: Antara Al-Farabi dan Khomeini. Bandung: Mizan, 2002.

Yazdi, Muhammad Taqi' Mishbah. Philisophical Instructions: An Introduction to Contemporary Islamic Philosophy, terj. Musa Kazhim dan Saleh Bagir. Bandung: Mizan, 2003.

Zar, Sirajuddin. Filsafat Islam: Filosof dan Filsafatnya. Jakarta: RajaGrafindo Persada, 2012.

Zuhri. Etika: Teori dan Praktek. Yogyakarta: FA Press, 2016. 
